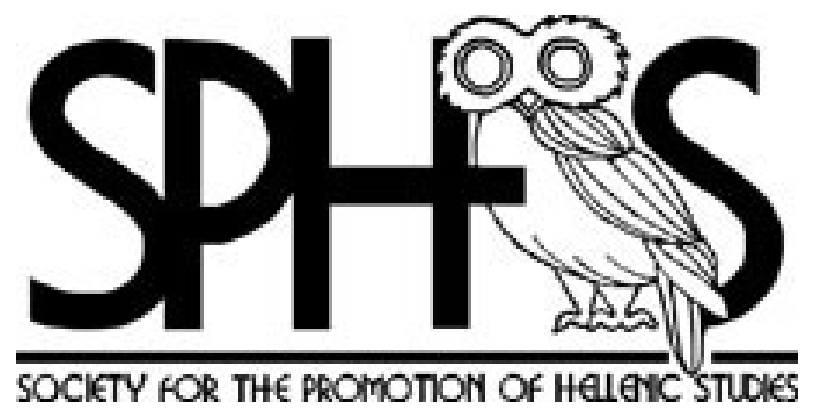

On the Gold and Silver Mines of Siphnos

Author(s): J. Theodore Bent

Source: The Journal of Hellenic Studies, Vol. 6 (1885), pp. 195-198

Published by: The Society for the Promotion of Hellenic Studies

Stable URL: http://www.jstor.org/stable/623394

Accessed: 09/07/2014 20:16

Your use of the JSTOR archive indicates your acceptance of the Terms \& Conditions of Use, available at

http://www.jstor.org/page/info/about/policies/terms.jsp

JSTOR is a not-for-profit service that helps scholars, researchers, and students discover, use, and build upon a wide range of content in a trusted digital archive. We use information technology and tools to increase productivity and facilitate new forms of scholarship. For more information about JSTOR, please contact support@jstor.org.

The Society for the Promotion of Hellenic Studies is collaborating with JSTOR to digitize, preserve and extend access to The Journal of Hellenic Studies. 


\section{ON THE GOLD AND SILVER MINES OF SIPHNOS.}

WHEN on a visit to this island last winter, I felt much curiosity about the almost legendary gold and silver mines of Siphnos, which in former ages made the inhabitants so rich, and which enabled them to build their 'Prytaneum and whitebrowed Agora.' The story of these mines we owe to Herodotus, and as the veracity of the statements of this historian, so far as Orientalism is concerned, is being sorely impugned just now, it will be satisfactory to find that on Hellenic subjects he does not entirely draw on his imagination. He tells us that the Siphniotes were the richest of all the islanders, owing to the gold and silver mines which existed there, but that they were mean in their donations to the oracle at Delphi, and hence the Pythian oracle prophesied ill for them. 'When in Siphnos there shall be a white Prytaneum, and a white-browed Agora, then will they have need of a shrewd man to protect them from the wooden troop and red herald.' When the Samian fugitives came and sacked their town, the Siphniotes recognized too late the purport of this warning, for the Samiotes came in boats painted with red paint, doubtless with the miltos or red paint, mines of which still exist in the neighbouring island of Keos.

There is another version of this story, and one which bears obviously on the mines, and which we read in Pausanias. The Siphniotes sent as an annual tribute to the shrine of Delphi a golden egg; but, being an astute race, they doubtless thought their gold might be better employed at home, so they sent a gilded egg, whereat Apollo was so enraged that he subrnerged their mines. This is one of the stories attached to the frequent motions of the earth's crust and consequent encroachments of 
the sea, which in former ages took place in the Aegean sea. We have the story of Delos being raised out of the waves for the birth of Apollo, we are told how Apollo himself raised up Anaphe out of the sea as a refuge for the Argonauts, and in our own times we have seen an island rise up from the sea at the volcanic Santorin. This Siphniote legend is a parallel case.

Many ancient writers speak of these gold and silver mines besides Herodotus, Pausanias, Strabo, Pliny, and others; and on making inquiries in the island I was told of two spots where it was commonly supposed ancient mining operations had taken place. The first of these to which we went is called 'the hole of the Holy Saviour,' from a little church close to, or 'refuges'

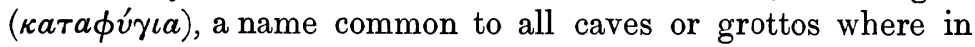
disturbed times a retreat could be found in case of the descent of pirates on the coast. It is a long ride from the cluster of villages where the modern life of Siphnos exists, not far from the ruins of the ancient town, to this point. The entrance to the hole is near the sea, to the north-east of the island; it is a very small entrance indeed, but leads to a perfect labyrinth inside, so that any one who wishes, I was told by my guide, could wander før many hours without finding the end, and that the danger of being lost was very great without a guide. This I fully realized during my short stay in the cave. Evidently the precious metal must have been in veins, which these multitudinous passages followed up; along the sides there were quantities of niches, where the workmen evidently put their lamps.

The appearance of this mine inside is as if sparkling with silver, and the stones we broke off from the side had the weight and colour of lead; there were stalactites here and there, as if water had percolated through, but no appearance of soil whatsoever. Numerous tools have been found inside, pointed and cone-shaped axes, and the marks of these instruments are visible on the walls.

The exterior however is the most interesting, for on the cliff, close to the sea-shore, exist certain hollows, called by the people Kanivıa furnaces, and in these it would appear that the smelting of the precious metal took place by the admixture of other metallic substances, such as iron and volcanic stones, which 
contributed to the quicker liquefaction. All round these hollows are quantities of scoriae, which the ancient smelters have used and cast on one side, especially on the hill side, near a small church dedicated to St. Silvester, and from which the spot is called by the natives $\Lambda \in i$ i $a \nu a$, or 'the remains.'

It was fortunately a very calm day, and by going in a boat and taking with us a 'sea telescope,' as they call it in these parts, being a tin can with a glass bottom, which, when put into the water below the ripple, makes it easy to distinguish objects at the bottom of the sea in shallow water, we were able to see traces of scoriae and hollows similar to those we had just seen, far below the surface of the water. This proves beyond a doubt that either the land must have subsided, or the sea encroached, since the time when the furnaces were used, and corroborates the substance of the legend as told by Pausanias. It is probable that below the present sea-level would be found the entrance into the mine, which was being worked at the time of the inundation, and that the mine which we had entered had been previously exhausted.

The second mine which we visited lay on the slopes of Mount Prophet Elias, to the north-west of the island, at a spot called 'the fissures' or Ká $\psi a \lambda o \nu$, a word used for 'fuel,' and probably referring to the quantity of burnt stones which lie in all directions. The entrance to this mine has only been lately discovered, being hidden by the thickness of the brushwood all around; owing to the burning of some of it a short time ago the entrance so long concealed from view was disclosed. On entering, the same features are disclosed as in the other mine, the appearance of the sides is silvery, and winding passages lead in all directions, and on chipping bits off there is a curious metallic ring. Inside have been found pieces of broken jars and lamps, which were doubtless in use at the time of the working of the mine. There are traces of sulphur here on the sides of the walls.

It is a curious fact that during the rainy season the far-famed potters of Siphnos come to the spot and pick up in the stream bits of vitrified lead, which they use for mixing with their clay to prevent its expanding; undoubtedly this comes from the smelting which once went on here, and this suggests another subject. Pliny tells us how celebrated were the potters of Siphnos, and 
that clay was found three stadia from the sea, which made an exceedingly prized pottery, becoming black and hard when exposed to the fire and rubbed with oil. This clay is not found to-day, but nevertheless the potters of Siphnos are celebrated throughout Greece. In the spring time they start on their travels far and wide, and settle in towns and villages for days and weeks, until the place is supplied with large and well-made earthenware, amphorae, and cooking utensils.

On the adjacent island of Seriphos there are numerous traces of ancient mining operations. Above the town, cut on a rock very difficult of access, is an inscription in large badly-formed letters, as follows :-

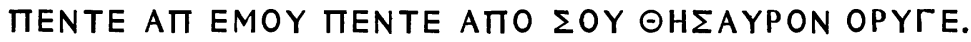
What can this mean-'Five from me, five from you, dig up a treasure'? Does it refer to the mines of Seriphos? Not far from the spot we saw a magnet mine, where the earth sticks to the point of a knife; probably this inscription refers to co-aperation with a view to working this treasure.

\section{J. Theodore Ben't.}

13, Great Cumberland Place. 